\title{
Bone, Mattompang Arajang, 'Kayu Galadupa' (Sindora galedupa; Fabaceae) dan Jejaring Bugis Nusantara
}

Ary Prihardhyanto Keim

Muhamad Nikmatullah

Nissa Arifa

Tukul Rameyo Adi

Wardah

Wawan Sujarwo

Email korespondensi
Kelompok Penelitian Etnobiologi, Pusat Penelitian Biologi, Lembaga Ilmu Pengetahuan Indonesia

Kelompok Penelitian Etnobiologi, Pusat Penelitian Biologi, Lembaga Ilmu Pengetahuan Indonesia

Kelompok Penelitian Etnobiologi, Pusat Penelitian Biologi, Lembaga Ilmu Pengetahuan Indonesia

Kementerian Koordinator Bidang Kemaritiman dan Investasi, Jakarta

Kelompok Penelitian Etnobiologi, Pusat Penelitian Biologi, Lembaga Ilmu Pengetahuan Indonesia

Kelompok Penelitian Etnobiologi, Pusat Penelitian Biologi, Lembaga Ilmu Pengetahuan Indonesia

arypkeim@yahoo.com

\begin{abstract}
The result of this current study shows that Bone as the centre of origin of the Bugisnese civilization is still preserving most of the original tradition alive like the Mattompang Arajang procession, which is now connected with the Anniversary of the City of Watampone, the capital of Bone Regency. Mattompang Arajang procession involves an important component, which is burning the incense. In the past, the incense burned was the indigenous Sulawesi incense known as 'kayu Galadupa' (thus the name of the resin is 'Kemenyan Galadupa' or Galadupa incense), which is identified here as the resin harvested from Sindora galedupa (Fabaceae). The species is very rarely seen in the forest now and this gave impact to the production of the resin. The Galadupa incense has not been used for many years and slowly forgotten and replaced by the more common Sumatran incense harvested from Styrax benzoin or $S$. sumatrana (Styracaceae). The Mattompang Arajang yearly procession also acts as a uniting moment for Bugisnese descents throughout Nusantara (i.e. Malay Archipelago and beyond). The prospect of creating a Nusantara Bugisnese Networking is also discussed. In connection with the Mattompang Arajang procession, as the procession is regarded deeply rooted in the Bugisnese existence, the indigenous incense should have been implemented and preserved. This is good news for the conservation of the Galadupa tree, Sindora galedupa in its own homeland.
\end{abstract}

Keywords: Bugis, Fabaceae, galadupa, incense, Mattompang, Sindora galedupa 


\section{PENDAHULUAN}

Masyarakat Watampone sebagian terbesar berasal dari suku Bugis (Pelras, 1979; Pelras, 1996; Druce, 2009; Druce, 2016). Bahkan suku dan bahasa Bugis adalah suku dan bahasa yang paling dominan dan tersebar paling luas di belahan selatan Sulawesi (Sarasin dan Sarasin, 1905; Gambar 1). Terbitan oleh Petri (1671) adalah termasuk salah satu rekaman awal oleh bangsa Eropa yang cukup rinci perihal suku Bugis, termasuk kepercayaannya, di mana di dalamnya tercatat upacara yang menyangkut orang-orang suci dan disucikan seperti "Bissu" dan benda-benda pusaka kerajaan. Rumphius di tahun 1675 (Rumphius, 1910; Rumphius, 2002) mencatat bahwa orang-orang Bugis dan Makassar adalah pedagangpedagang utama dalam perniagaan di Ambon yang memperdagangkan komoditas rempahrempah antar pulau-pulau di Maluku dan luar Maluku, di mana untuk komunikasi di antara mereka, digunakan Bahasa Bugis.

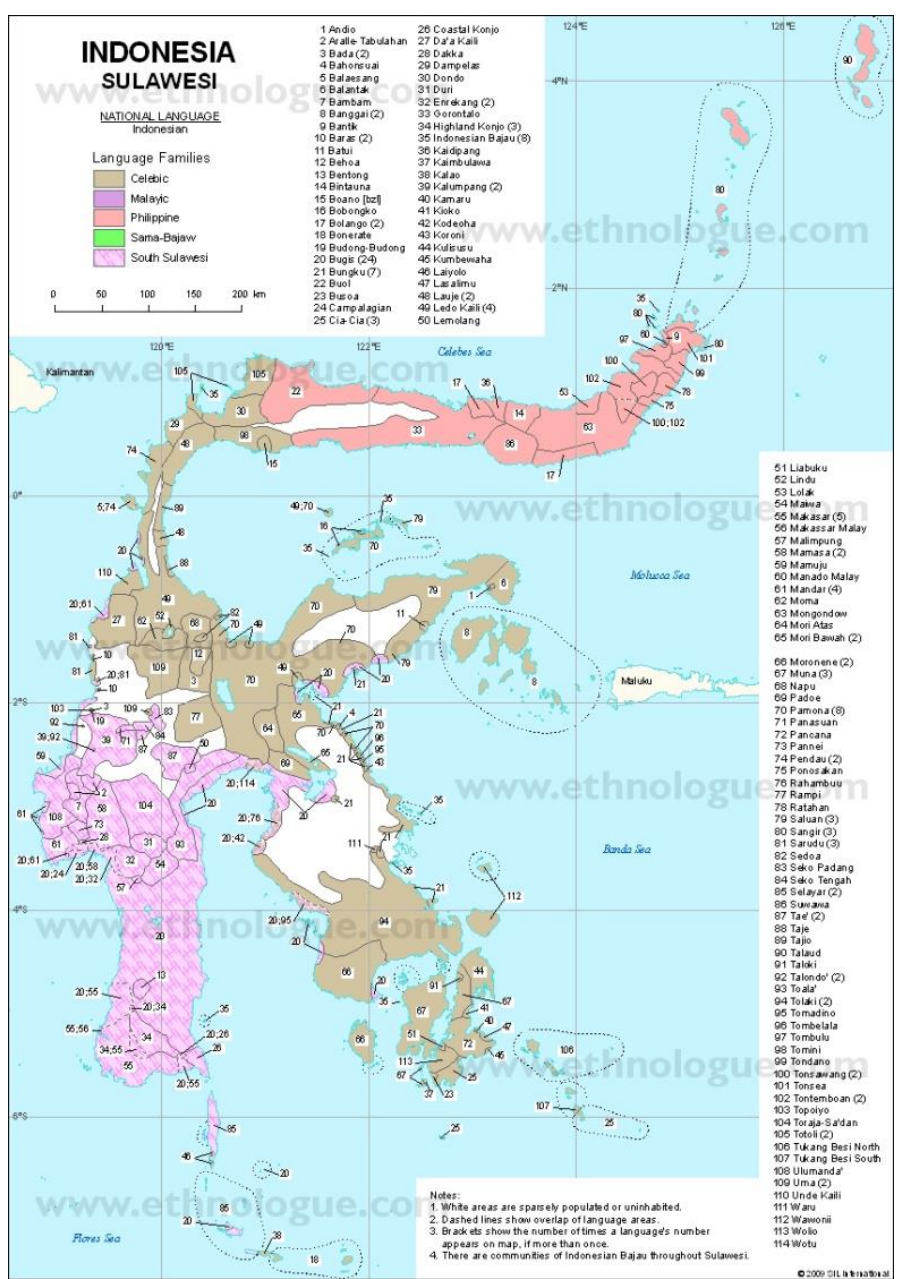

Gambar 1. Peta persebaran bahasa-bahasa daerah di Sulawesi

[Sumber: www.ethnologue.com]

Bahasa Bugis bahkan dicatat Rumphius (1705; 1741a) sebagai bahasa komunikasi utama antar suku-suku yang berasal dari bagian selatan Pulau Sulawesi, seperti Bugis sendiri, Buton, Makassar, dan Mandar. Luasnya pemakaian Bahasa Bugis sebagai bahasa pergaulan (lingua franca) di masyarakat Sulawesi Selatan selaras dengan kemampuan bahari suku Bugis itu sendiri yang membuat mereka dapat menjelajah wilayah-wilayah yang luas membentuk jalinan perdagangan (tradingnetwork) di Nusantara dan lebih jauh lagi hingga 
India, Timur Tengah, dan Afrika (Pelras, 1996). Rheede tot Drakenstein (1678) bahkan mencatat bahwa sebagian besar pedagang dari arah timur Malabar, India berasal dari Jawa, Sumatera, dan Celebes. Mereka saling bertutur dalam Bahasa Jawa, Melayu atau Bugis. Rheede tot Drakenstein (1678) juga menambahkan bahwa para pedagang dari timur ini sudah berdagang di India jauh sebelum kedatangan bangsa-bangsa Eropa, bahkan juga sebelum kedatangan para saudagar Muslim dari Timur Tengah.

Salah satu tokoh suku Bugis yang sangat terkenal dan dikagumi adalah Aru Palakka atau Arung Palakka dalam Bahasa Bugis. Arung Palakka adalah Sultan Kesultanan Bone yang ke-15, yang memimpin perjuangan kemerdekaan Kesultanan Bone dari Kesultanan Gowa, namun penelitian ini tidak ditujukan untuk membahas lebih dalam tentang tokoh sejarah tersebut. Bagi yang berminat dapat merujuk lebih jauh terutama pada Andaya (1981), Pelras (1996) dan Sila (2015) dalam kaitan dengan kebudayaan dan masyarakat Bugis itu sendiri.

Penelitian ini lebih merujuk kepada literasi budaya Maritim yang ada dalam masyarakat dan kebudayaan Bugis yang belum banyak diungkap yang mana juga masih berkaitan dengan Arung Palakka dan kemampuannya menguasai perdagangan rempah di Nusantara pada abad ke-17 dan warisan yang ditinggalkannya bagi masyarakat Bugis, terutama di kampung halaman suku Bugis itu sendiri yang sekarang secara administratif berada dalam wilayah Kabupaten Bone. Juga bagaimana masyarakat Bugis, sebagai sebuah masyarakat yang jelas berbudaya berbasis maritim membangun jaringan perdagangan di Nusantara, bukan mengkajinya secara mendalam seputar sejarah asal muasal tradisi tersebut, yang sudah banyak diulas oleh para cendekiawan sebelumnya di atas, namun lebih kepada bagaimana basis kebudayaan maritim tersebut di-revitalisasi di masa kini, terutama dalam membangun jaringan perekonomian berbasis kekerabatan Bugis dalam kaitan dengan mendukung program pemerintah terkait Poros Maritim berbasis rempah dan produk-produk unggulan lain Indonesia. Penelitian ini mengkaji kemenyan asli suku-suku Bone dan Makassar khususnya dan Sulawesi pada umumnya yang dikhawatirkan sudah sangat langka.

\section{METODE}

\section{Lokasi Penelitian}

Watampone adalah ibukota Kabupaten Bone, Propinsi Sulawesi Selatan yang berjarak sekitar 170,1 Km sebelah Timur Laut kota Makassar. Watampone memiliki iklim tropis dengan suhu udara berkisar antara $26^{\circ}$ hingga $34^{\circ} \mathrm{C}$, kelembaban $95 \%$ hingga $99 \%$, dan curah hujan kurang dari $1750 \mathrm{~mm}$ hingga $3000 \mathrm{~mm}$ per tahun, dengan musim basah/hujan antara bulan April hingga September, dan musim kering/kemarau dari bulan Oktober hingga Maret. Watampone didominasi oleh dataran rendah dengan ketinggian kurang dari $500 \mathrm{~m}$ dpl. Meski begitu perjalanan dari Makassar menuju Watampone via Maros melewati dua Pegunungan yang membelah bagian selatan Pulau Sulawesi, Pegunungan Kapur/Karst Maros (atau dalam literatur lama dikenal sebagai Western Divide Mountain dan Pegunungan Bone (Van Leeuwen, 1981). Komposisi batuan dan tanah Watampone sebagian besar adalah dari batuan gunung api dari masa Kenozoikum (66 juta tahun lalu hingga sekarang), termasuk juga sedimen batuan dari jaman Miosen (23,030 hingga 5,332 juta tahun lalu) - Pliosen (5,332 hingga 1,806 juta tahun lalu), yaitu meliputi batuan lempung, batuan pasir, dan sedimen vulkanis (Van Leeuwen, 1981). Selain itu juga sedimen dari jaman Kuarter (Quaternary, 2,58 juta tahun lalu hingga sekarang; Whitten dkk., 1987; Gambar 2). 


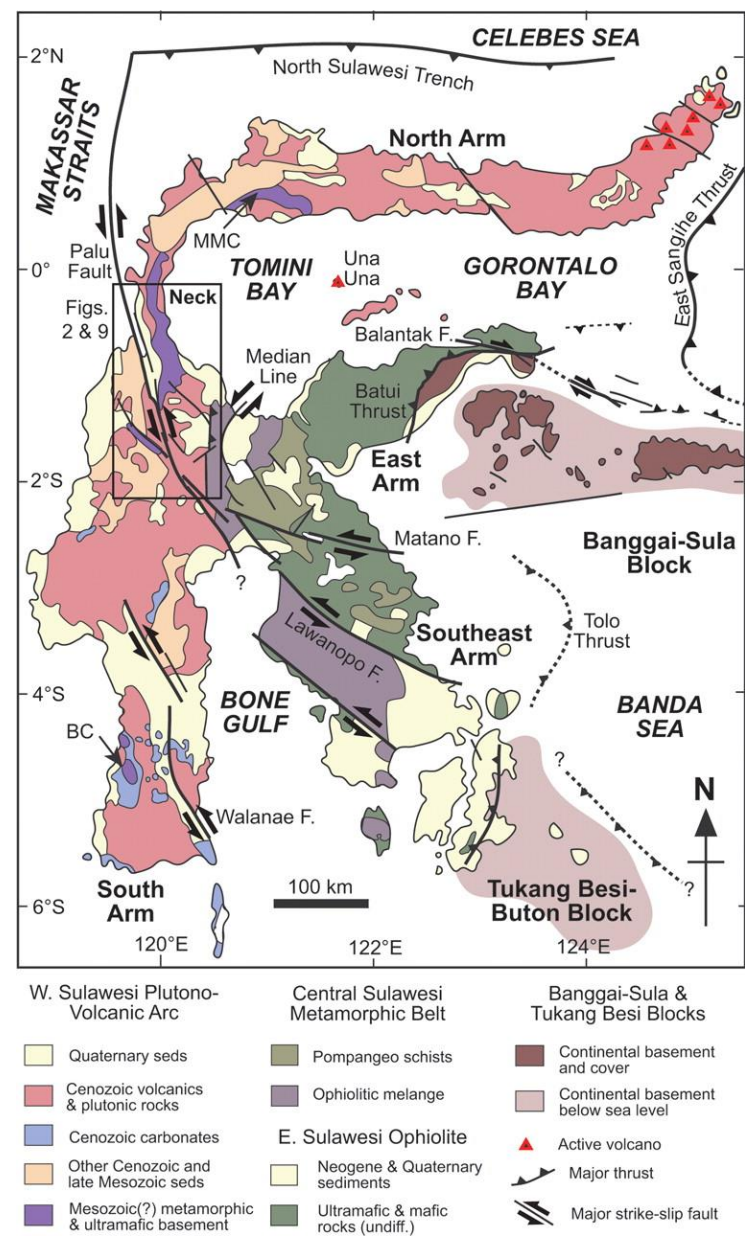

Gambar 2. Peta geologi Sulawesi

[Sumber: Whitten dkk., 1987]

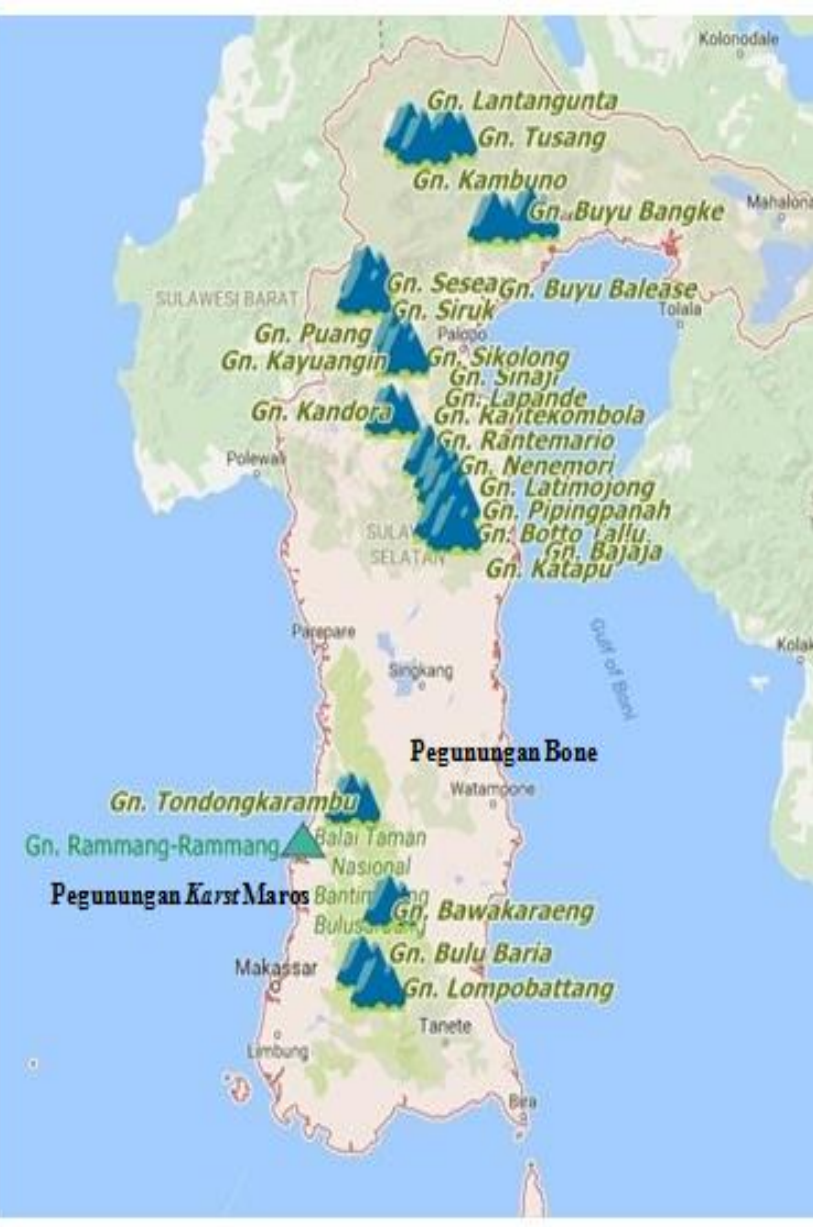

Gambar 3. Gunung-gunung berapi di Propinsi Sulawesi Selatan

[Sumber: www.infopendaki.com]

Komposisi batuan dan tanah asal kegiatan vulkanik sangatlah masuk akal sejalan dengan tingginya jumlah gunung api (baik yang masih aktif maupun non aktif) di Propinsi Sulawesi Selatan, khususnya setidaknya empat gunung berapi di kawasan Makassar-MarosBone, seperti Gunung Bawakaraeng, Bulu Baria, Lompobattang, Tondongkarambu, dan Rammang Rammang serta gunung-gunung api lainnya di bagian tengah dan utara Sulawesi Selatan (Gambar 3).

Kehadiran tanah tipe kapur (limestone) juga sangat jelas (Gambar 4) dan ini selaras dengan sejarah geologi Sulawesi itu sendiri yang merupakan kesatuan dari pulau-pulau samudera (oceanic islands) dari masa Kenozoikum serta tidak pernah bergabung dengan masa daratan besar (baik Paparan Sunda maupun Paparan Sahul), dengan sendirinya pulaupulau samudera tersebut terbentuk awalnya dari pulau karang atau atoll (Hoent dan Ziegler, 1917). Van Bemmelen, 1949; Audley-Charles, 1981; Metcalfe, 1996; Hall, 1998; Holloway dan Hall, 1998). Penyatuan pulau-pulau samudera tersebut sendiri tidak lepas dari aktivitas tumbukan dan lipatan yang ditunjukkan dengan tingginya tingkat aktivitas vulkanis dan tektonis di Sulawesi saat itu yang juga ditunjukkan dengan type batuannya (lithology) sebagaimana disebutkan di atas (Van Leeuwen, 1981). Kondisi geologi di atas mendasari kebijakan pembangunan jalan raya dan jalan kereta api di Sulawesi, khususnya Sulawesi bagian tengah dan selatan. 


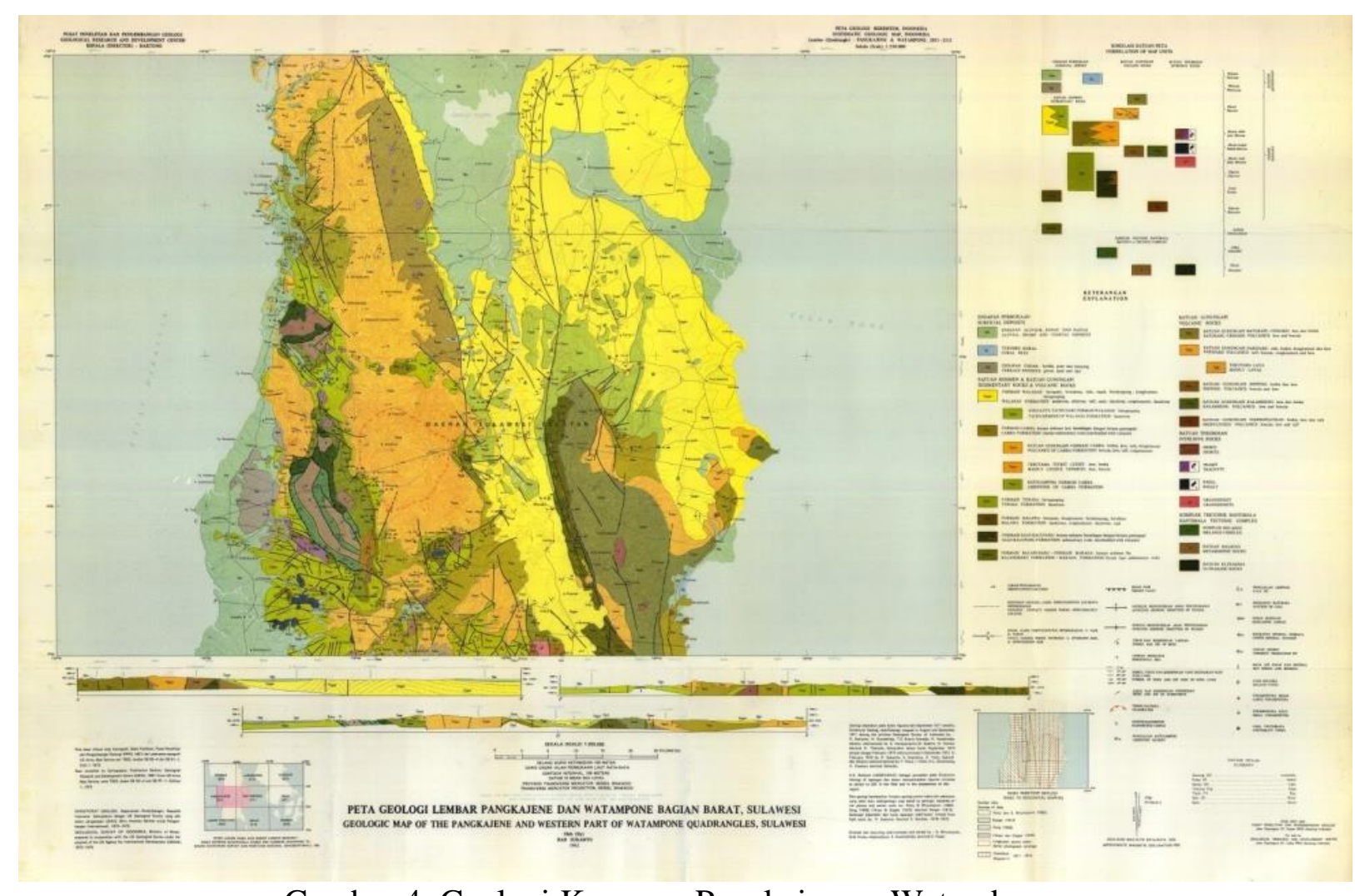

Gambar 4. Geologi Kawasan Pangkajene - Watambone

[Sumber: Hoent dan Ziegler, 1917]

Walaupun di sekitar kota Watampone sendiri tidak terdapat hutan, namun di kawasan sekitar kota, terutama ruas jalan antara Kabupaten Maros dan Bone, masih ditemukan percakan-percakan hutan dengan tipe Hutan Hujan Tropika Dataran Rendah (Whitten dkk., 1987) lengkap dengan jenis-jenis tumbuhan endemik Sulawesi atau yang persebarannya mencakup Sulawesi yang hidup di dataran rendah seperti Diospyros celebica (Ebenaceae), D. maritima, Kjellbergiodendron celebicum (Myrtaceae), Koordersiodendron pinnatum (Anacardiaceae), dan beberapa jenis lainnya (Koorders, 1898; Koorders-Schumacher, 1914; Lam, 1945a; Lam, 1945b; Merrill, 1952; Keßler dkk., 2002), yang mana sebagiannya tergolong jenis-jenis penghasil kayu potong (timber) utama (Lemmens dkk., 1995). Sulawesi pun memiliki banyak jenis hewan endemik (Whitten dkk., 1987), beberapa di antaranya yang terkenal adalah:

a. Dua jenis Anoa, Anoa Dataran Rendah (Bubalus depressicornis) dan Anoa Dataran Tinggi (Bubalus quarlesi).

b. Tiga jenis Babirusa (dari semula hanya satu jenis, Babyrousa babyrussa), yaitu Babirusa Sulawesi Selatan (Babyrousa bolabatuensis), Babirusa Sulawesi (Babyrousa celebensis), dan Babirusa Togian (Babyrousa togeanensis). Babyrousa bolabatuensis diyakini sebagai jenis Babirusa yang menghuni hutan hujan tropika dataran rendah di sekitar jalur Maros-Watampone.

c. Delapan jenis monyet dari marga Macaca adalah endemik Sulawesi (Supriatna dan Wahyono, 2000), yang mana salah satunya adalah Monyet Dare (Macaca maura) yang diketahui ditemukan di Sulawesi Tengah yang dekat dengan kawasan Kabupaten Bone. Tujuh jenis Tarsius endemik Sulawesi (Groves dan Shekelle, 2010), di mana di kawasan Watampone kemungkinan terdapat Tarsius Sulawesi (Tarsius tarsier) dan Tarsius Kerdil (Tarsius fuscus). 
d. Burung Maleo (Macrocephalon maleo), satu-satunya jenis di marga tersebut. Keberadaan di kawasan Watampone belum pernah dilaporkan secara ilmiah meski banyak masyarakat yang melaporkan.

\section{Pengumpulan Data}

Metode yang dipakai adalah eksplorasi dan keikutsertaan (partisipasi) langsung dengan wawancara secara terbuka dua arah (Martin, 1995; Cunningham, 2001; Bernard, 2006; Nolan dkk., 2011). Lokasi penelitian di Kota Watampone, terletak di bagian selatan Teluk Bone (Gambar 5), dengan sendirinya pergerakan air laut di teluk tersebut sangat mempengaruhi kondisi fisik Watampone. Kota Watampone memiliki luas $138,87 \mathrm{Km}^{2}$. Meski tidak langsung berada di tepi pantai, Watampone memiliki akses ke laut yang relatif dekat, di mana dari pusat kota ke pelabuhan utama, Pelabuhan Bajoe sekitar 9,4 Km dan dapat ditempuh dalam waktu sekitar 23 menit (Gambar 6).

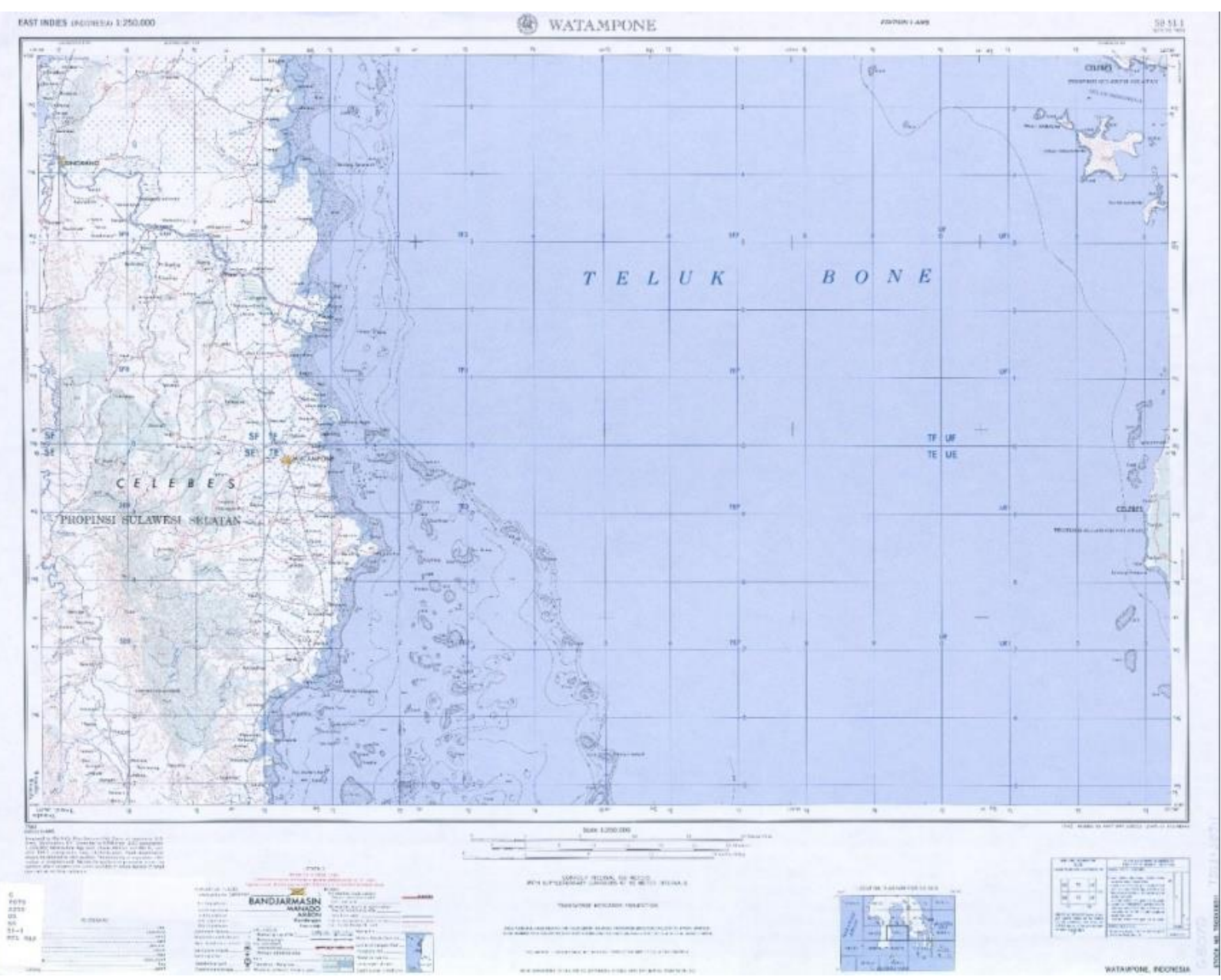

Gambar 5. Kota Watambone dalam kaitan dengan Teluk Bone [Sumber: Library of University of Texas] 


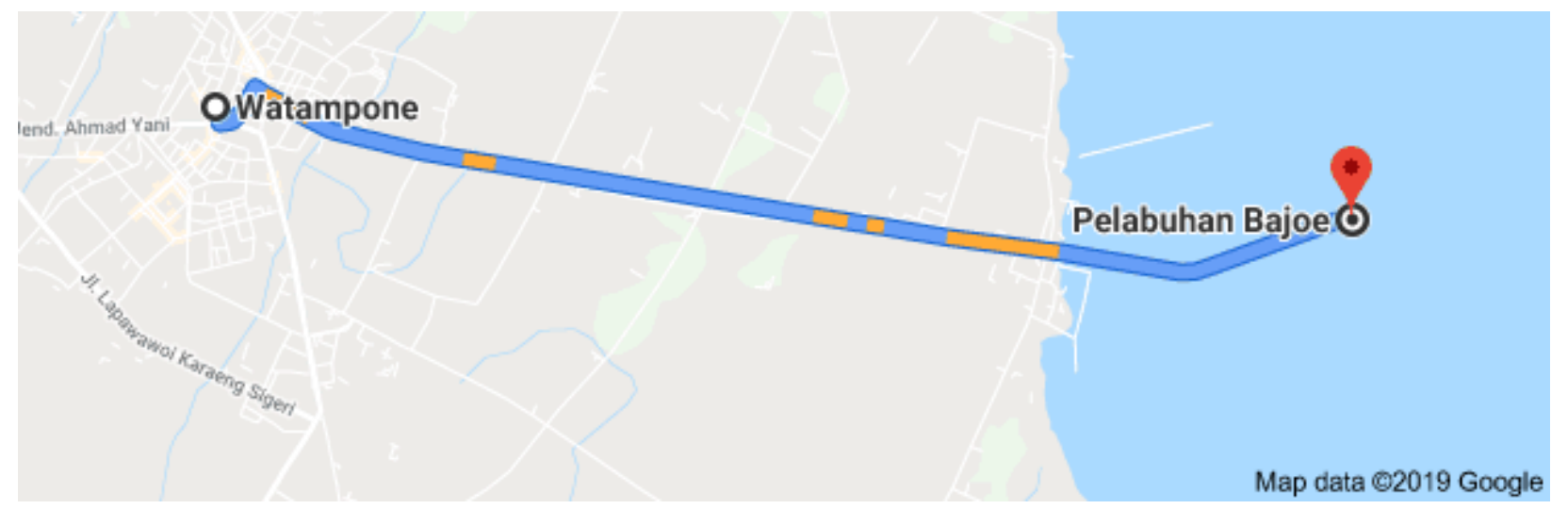

Gambar 6. Jalur darat antara pusat Kota Watampone ke Pelabuhan Bajoe

[Sumber: Google Map, 2019]

Meski Watampone juga memiliki Bandar Udara, yaitu Bandar Udara Arung Palakka yang rencananya akan diperluas runway-nya, namun saat ini hanya jalan darat yang berfungsi sebagai moda transportasi utama yang menghubungkan kedua kota tersebut, di mana perjalanan dari Makassar ke Watampone dalam keadaan normal dapat ditempuh dalam empat jam via jalan Poros Maros - Soppeng dan Poros Leppangeng - Watampone. Perjalanan darat tersebut melintasi Pegunungan Kapur/Karst Maros (masuk Kecamatan Camba, Kabupaten Maros) dan Taman Nasional Bantimurung Bulusaraung yang berlokasi di Kabupaten Maros dan Kabupaten Pangkajene dan Kepulauan (Gambar 7).

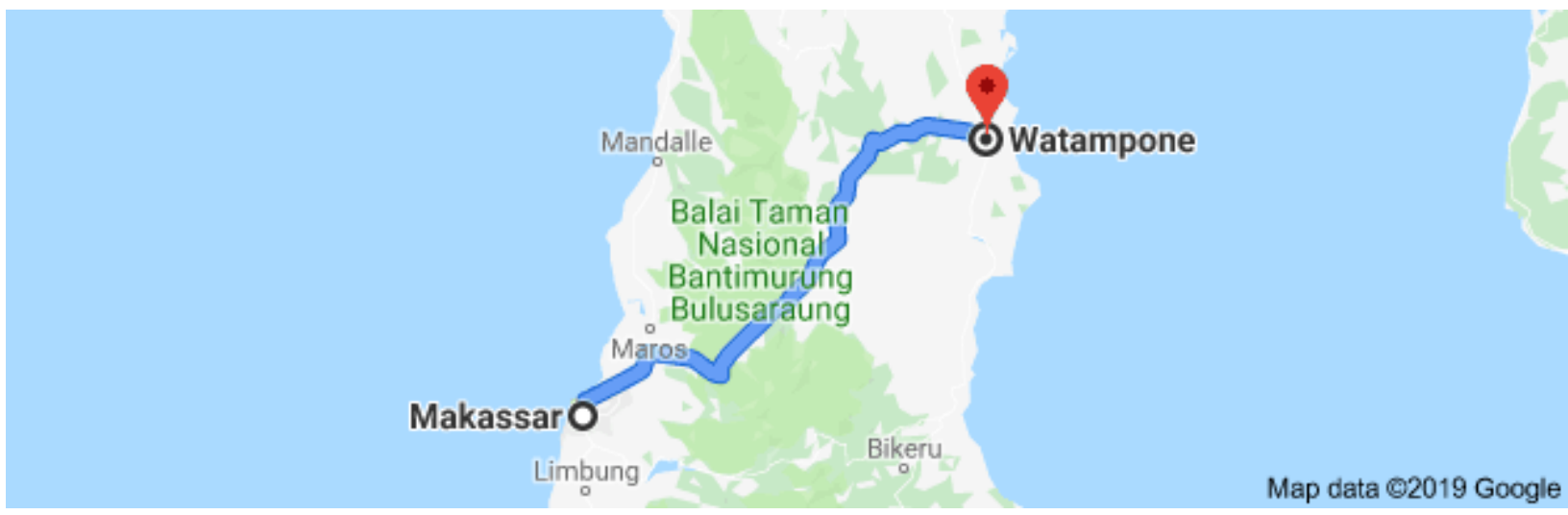

Gambar 7. Jalur darat antara Makassar ke Wartampone

[Sumber: Google Map, 2019]

\section{HASIL DAN PEMBAHASAN}

\section{Prosesi Mattompang Arajang}

Di masa silam prosesi Mattompang Arajang dilaksanakan oleh para Bissu atas restu raja atau Mangkau di dalam ruangan tempat penyimpanan benda-benda pusaka tersebut. Prosesi tersebut menjadi bentuknya seperti sekarang setidaknya semenjak masa pemerintahan Raja Bone ke-15, La Tenri Tatta Arung Palakka atau lebih dikenal di luar Bone sebagai Aru Palakka. Setidaknya terdapat lima macam benda pusaka Kerajaan Bone (secara keseluruhan disebut Parewa Arajanna Bone) yang disucikan dalam perhelatan tersebut, yaitu:

1. Teddung Pulaweng (Payung Emas) 
2. Sembangeng Pulaweng (Selempang Emas)

3. La Tea Riduni (Kelewang), terutama sebilah kelewang yang disebut Alameng yang adalah pusaka Raja Bone ke-15, Arung Palakka

4. La Salaga (Tombak) yang menjadi simbol kehadiran Raja Bone

5. Alameng Tatarapeng (Senjata adat tujuh atau Ade' Pitu)

Prosesi Mattompang Arajang sendiri sudah lama dilakukan dan sudah tercatat oleh orang luar Bone setidaknya semenjak abad ke-17 (Petri, 1671; Pelras, 1996; Said, 2004) terus dilestarikan hingga kini. Berbeda dengan tahun-tahun sebelumnya, bertepatan dengan Hari Jadi Bone yang ke-689 (pada tahun 2019), Pemerintah Daerah Kabupaten Bone menetapkan bahwa prosesi dilakukan di Lapangan Merdeka mengacu pada permohonan masyarakat Bugis yang ada di dalam dan luar Kabupaten Bone sehingga segenap masyarakat dapat menyaksikannya (Gambar 8). Segenap prosesi Mattompang Arajang dipimpin oleh seorang Bissu utama dan diiringi oleh para Bissu bawahannya dan para juru cuci pusaka yang bukan Bissu (Gambar 9 dan Gambar 10). Bissu sendiri adalah kelompok waria yang dianggap suci atau disucikan karena diyakini memiliki kekuatan supranatural (Pelras, 1996; Said, 2004). Meski begitu, Bissu bukanlah serta merta dukun dan tidak setiap waria dapat menjadi Bissu. Intinya adalah bahwa tidak pernah acara Mattompang Arajang dapat terselenggara tanpa kehadiran dan pimpinan Bissu. Sementara dalam pendapat lain, Bissu dianggap sebagai kaum pendeta yang dipandang sebagai separuh manusia dan separuh dewa yang bertindak sebagai penghubung antara alam manusia dan alam para dewa (Sharyn, 2002). Masyarakat tradisional Bugis sendiri menganggap Bissu sebagai manusia berjenis kelamin yang ke-lima karena dalam budaya Bugis dikenal keberadaan lima jenis kelamin manusia (Sharyn, 2001):

a. Oroane, laki-laki.

b. Makunrai, wanita.

c. Calalai, wanita yang berpenampilan seperti laki-laki.

d. Calabai, laki-laki yang berpenampilan seperti wanita.

e. Bissu, yang dianggap sebagai kombinasi dari ke-empat kelamin di atas.

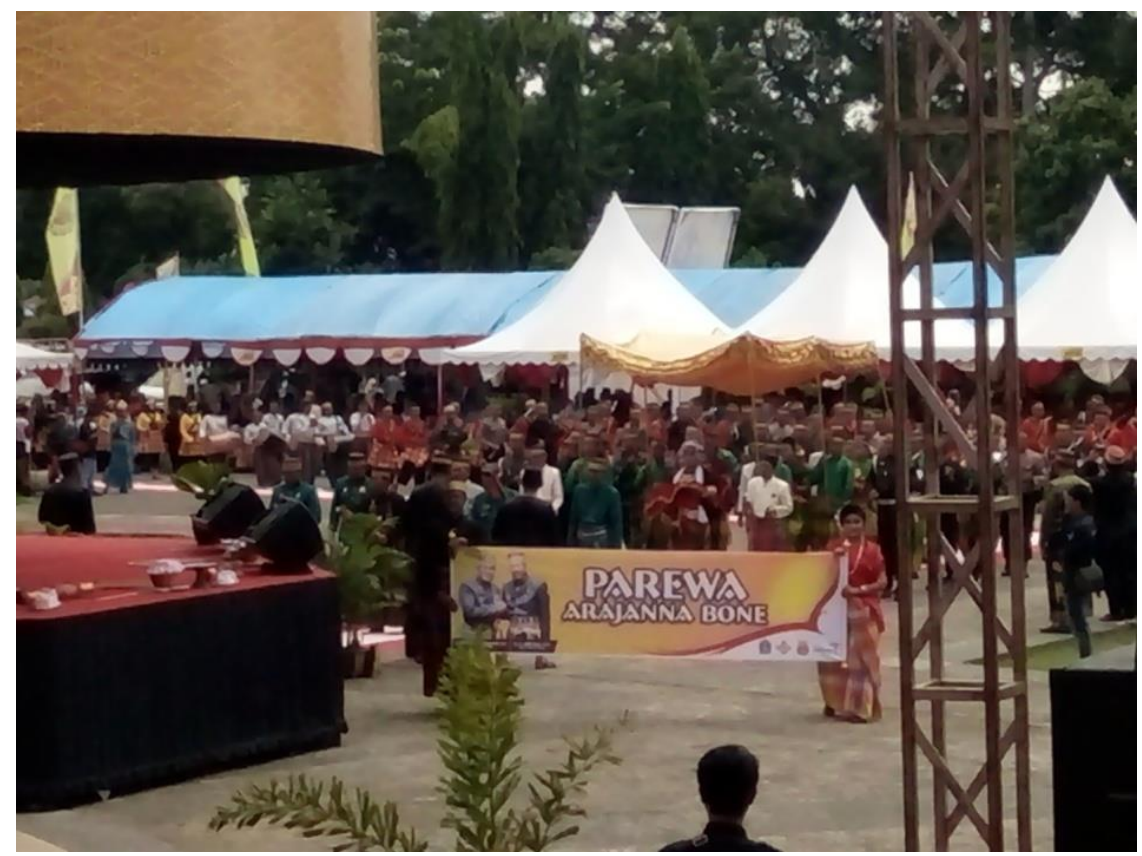

Gambar 8. Prosesi Mattompang Arajang (Pembersihan Benda Pusaka) tahun 2019 yang diselenggarakan di Lapangan Merdeka, Watampone 


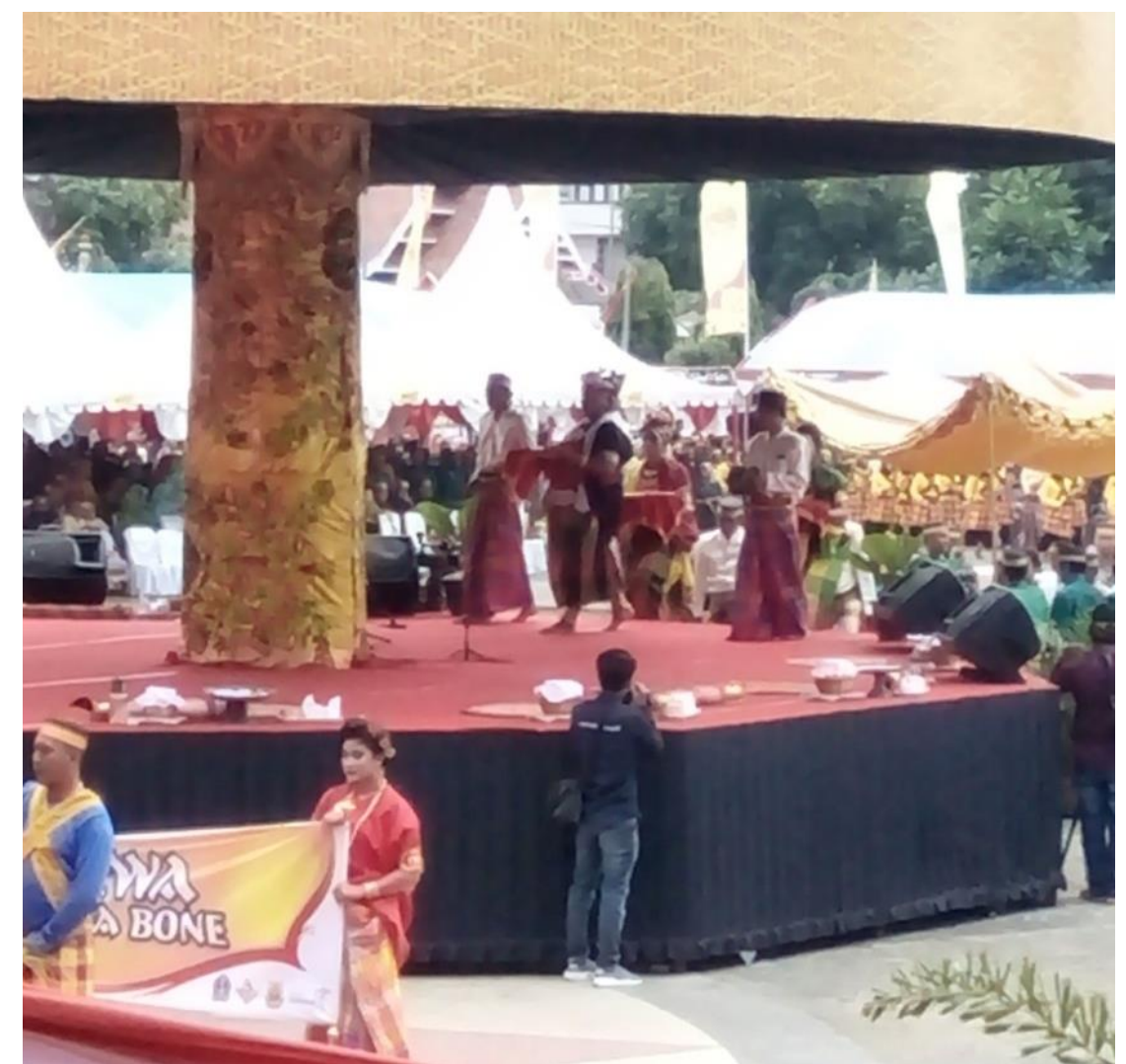

Gambar 9. Bissu utama memimpin prosesi Mattompang Arajang sambil membawa La Tea Riduni (Kelewang) yang diyakini milik Arung Palakka

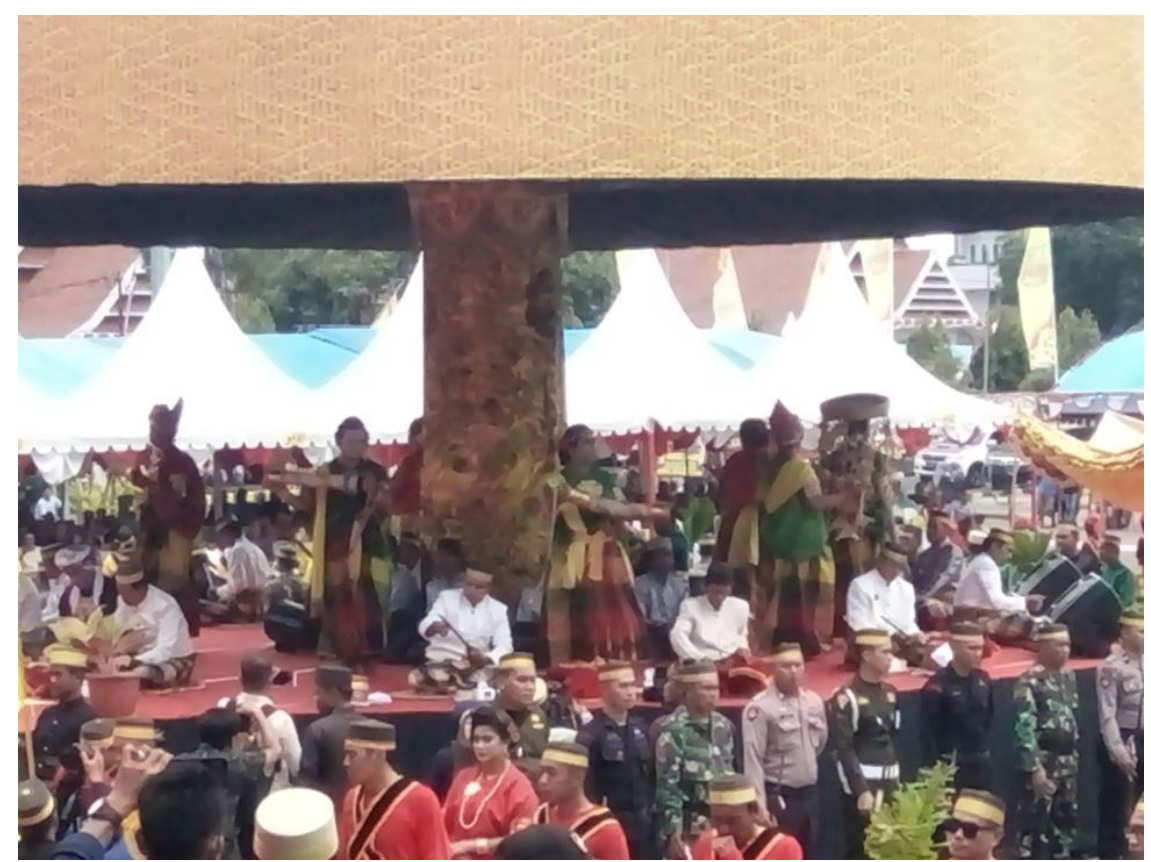

Gambar 10. Para Bissu menari sambil merapal mantera dalam prosesi Mattompang Arajang. Bissu utama duduk paling kiri, di sekitarnya duduk para juru cuci benda-benda pusaka Kerajaan Bone yang adalah bukan Bissu

Bissu sendiri unik dalam kebudayaan Bugis dan ini berasal dari tradisi lama suku Bugis jauh sebelum kedatangan agama-agama dari luar (Hindu, Buddha, dan Islam) ke tanah Bugis. 
Dengan kata lain, Bissu adalah unik untuk peradaban Austronesia, khususnya West-Central Austronesia karena konsep yang sama dengan itu juga ditemukan di banyak suku lain di kawasan tersebut seperti di Jawa (gemblak di tradisi Reog Ponorogo; Krismawati dkk., 2018; Wiranata dan Nurcahyo, 2018), Maori di Selandia Baru yang disebut takatāpui (Swain dan Trompf, 1995; Murray, 2003; Craig, 2004), Filipina yang disebut lakapati (Ramos, 1990), dan sebagainya.

\section{Kemenyan Bugis}

Dalam ritual pencucian benda-benda pusaka Kerajaan Bone tersebut dibakar kemenyan, bahkan asap kemenyan menjadi salah satu kelengkapan pencucian benda pusaka. Pembakaran kemenyan dilakukan oleh Bissu utama dan para juru cuci (bukan Bissu). Yang menarik di sini adalah kemenyannya itu sendiri. Sepanjang yang diketahui kemenyan Makassar dan Bugis berbeda dari kemenyan yang umum dikenal. Kemenyan yang umum dikenal berasal dari getah (resin) jenis-jenis tumbuhan Styrax benzoin ('kemenyan biasa'), Styrax paralleloneurus ('kemenyan bulu'), dan Styrax sumatrana ('kemenyan Toba'; Styracaceae). Kemenyan terbaik berasal dari resin Styrax sumatrana (Gambar 11) yang sudah dikenal dan diperdagangkan selama berabad-abad, mulai dari Nusantara sendiri hingga Timur Tengah dan Afrika. Ketiga jenis tersebut hanya ada di Sumatera, khususnya Propinsi Sumatera Utara dan dikenal dengan nama daerah Batak Tobasebagai "haminyon". Dari nama daerah itulah masuk ke dalam Bahasa Indonesia (i.e. Melayu) sebagai "kemenyan". Dalam bahasa-bahasa Nusantara lainnya disebut "dupa".

Jenis-jenis tersebut di atas tidak terdapat di Sulawesi, sehingga suku-suku di Sulawesi menggunakan resin dari tumbuhan lain, tentunya dari jenis tumbuhan penghasil resin yang terdapat atau tersebar luas di Sulawesi. Membakar dupa memang bagian dari ritual keagamaan asli bangsa Austronesia, yang mana suku-suku di Sulawesi termasuk di dalamnya. Ritual membakar kemenyan atau dupa bukan merupakan pengaruh dari Hindu Arya India. Rumphius (1741b) mencatat bahwa dupa orang Makassar berasal dari tanaman "Caju Galedupa" (Gambar 12) merujuk kepada nama tumbuhan tersebut dalam Bahasa Bugis dan Makassar yaitu 'Kayu Galadupa'. Jenis "Caju Galedupa" ini kemudian diidentifikasi oleh Merrill (1917) sebagai Sindora galedupa (Fabaceae), sejenis tanaman polong-polongan (legumes) yang menghasilkan resin (Boer dkk., 2000; Langenheim, 2003). 


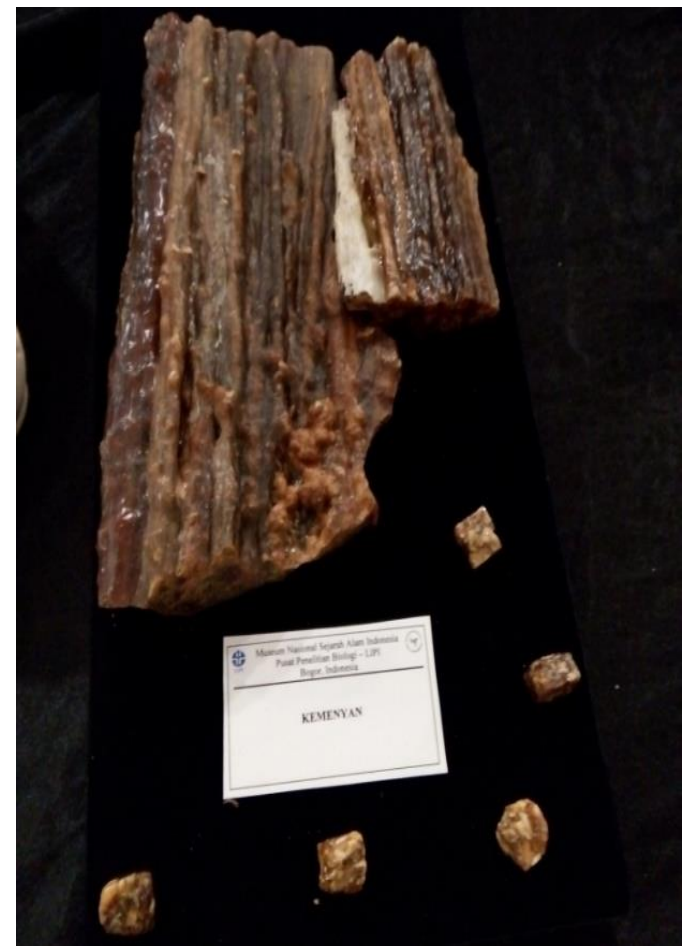

Gambar 11. Kemenyan Toba (Styrax sumatrana; Styracaceae)

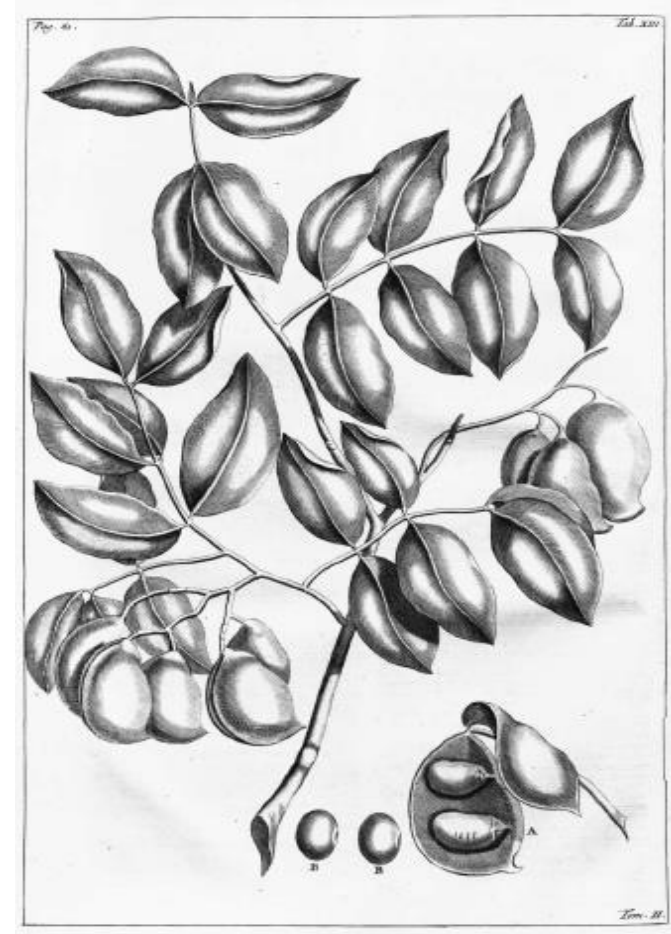

Gambar 12. 'Kayu Galadupa' atau Sindora galedupa (Fabaceae)

'Kayu Galadupa' sebagai penghasil bahan dupa sebenarnya sudah dapat diduga dari nama daerahnya sendiri. 'Gala' atau 'Galu' adalah nama daerah yang digunakan masyarakat berbahasa Bugis dan Makassar (juga bahasa-bahasa di bagian utara Sulawesi bahkan hingga ke Kepulauan Filipina; lihat Koorders, 1898) untuk menyebut seluruh jenis tumbuhan polong-polongan (Fabaceae atau Leguminosae) yang masuk ke marga Sindora, sehingga dengan sendirinya kata 'Galadupa' berarti kayu 'Gala' yang menghasilkan dupa. Dengan kata lain, dupa Bugis atau dupa Makassar. 'Kayu Galadupa' (Sindora galedupa) sendiri memang diketahui menghasilkan resin tipe oleoresin (Langenheim, 2003), meski tingkat keharumannya tidak seperti kemenyan yang dihasilkan oleh Styrax sumatrana ('kemenyan Toba') atau bahkan Styrax paralleloneurus ('kemenyan bulu'), namun resin yang dihasilkan Sindora galedupa cukup wangi untuk dijadikan dupa (Boer dkk., 2000) yang digunakan dalam ritual keagamaan masyarakat Bugis dan Makassar di masa silam (Petri, 1671; Pelras, 1979; Pelras, 1996; Said, 2004; Sila, 2015). Selain menghasilkan dupa, kayu dari Sindora galedupa juga dijadikan bahan bangunan dan kerajinan (Gambar 13). Selain itu kayunya juga dipakai sebagai bahan pembuatan perahu, terutama perahu yang ringan namun cukup kokoh sehingga dapat menjadi perahu cepat. 'Kayu Galadupa' dikenal sangat cocok untuk kategori perahu angkut, seperti Pinisi atau Padewakang, selain karena berat jenisnya cukup baik (Whitmore, 1972), juga karena resin yang dihasilkan tersebut berfungsi sebagai anti rayap sehingga membuat kayunya awet sekaligus kedap air karena resin yang dihasilkan di urat-urat kayu dapat berfungsi seperti gum arabicum (Lemmens dkk., 1995).

Penelitian ini juga mengungkap apakah kemenyan yang digunakan dalam ritual Mattompang Arajang masih menggunakan dupa asli Bugis atau Makassar sebagaimana yang dilaporkan Rumphius (1741b)? Ternyata kemenyan yang dipakai bukan berasal dari resin "Caju Galedupa" atau 'Kayu Galadupa' (Sindora galedupa), melainkan kemenyan import dari Saudi Arabia. Bahkan semua Bissu dan Juru Cuci Benda Pusaka tidak mengetahui tentang 'kemenyan Bugis' meski mereka pernah mendengar dari para senior mereka bahwa di 
masa silam para Bissu membakar 'dupa Bugis' yang khas dan berbeda dengan dupa yang kebanyakan diketahui. Sayangnya, mereka tidak dapat menjelaskan seperti apa 'kemenyan Bugis' tersebut dan bahkan kaget mengetahui bahwa kemenyan itu adalah getah yang mengeras (resin) dan dipanen dari tumbuhan. Sangat jelas sekali bahwa ada literasi yang hilang. Dengan kata lain, ada pengetahuan tradisional mereka terkait kemenyan atau dupa Bugis (dupa Makassar) yang sudah hilang dari ingatan mereka.

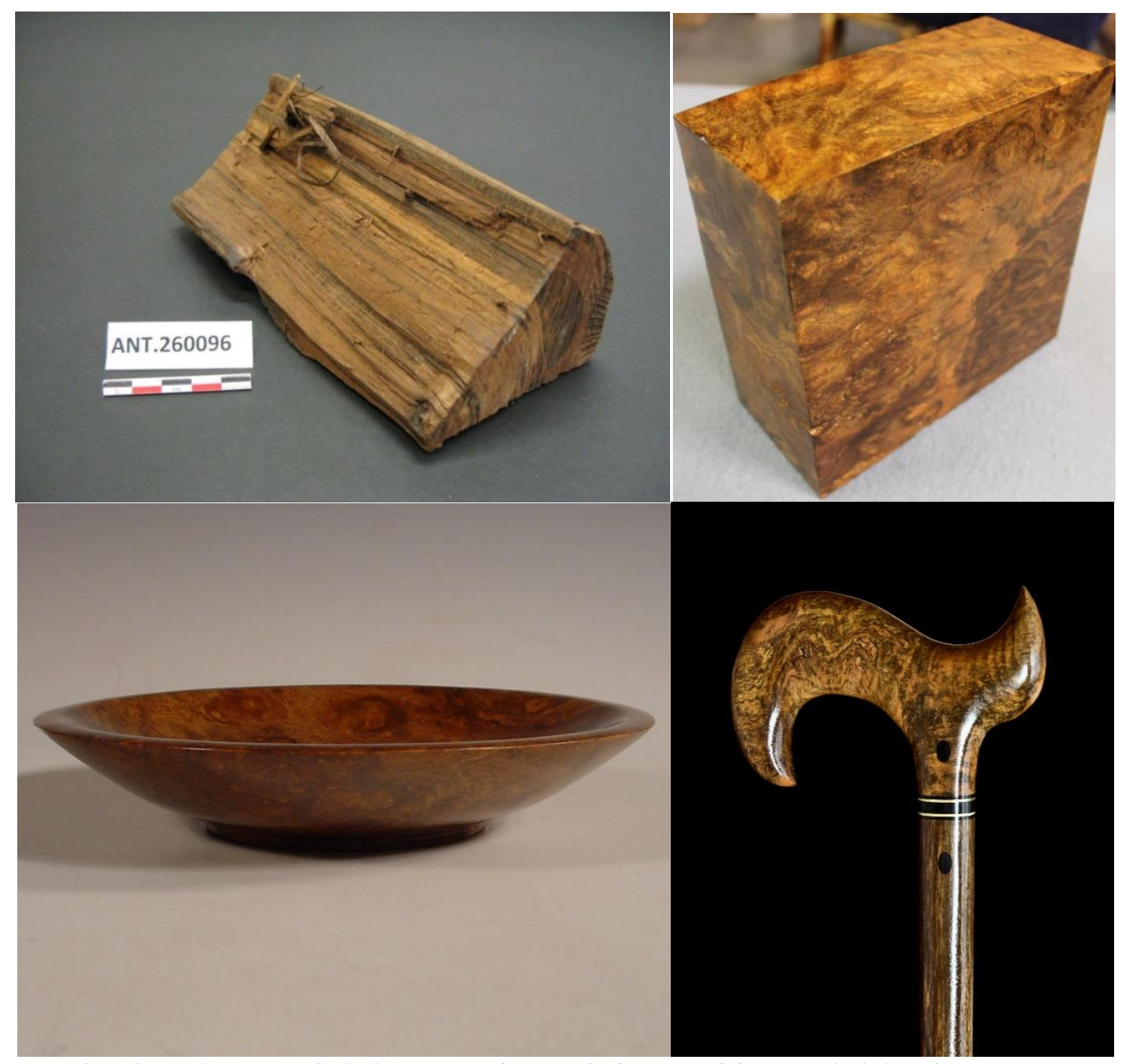

Gambar 13. 'Kayu Galadupa' (Sindora galedupa). Kiri atas = belahan kayu yang memperlihatkan kelenjar-kelenjar getah atau resin (warna hitam), kanan atas = balok kayu, kiri bawah $=$ kerajinan berupa piring kayu, kanan bawah $=$ kerajinan berupa tongkat kayu [Sumber: www.pinterest.com]

Hilangnya literasi akan 'kemenyan Bugis' tersebut diyakini berkaitan langsung dengan langkanya 'kayu Galadupa' (Sindora galedupa) itu sendiri di alam, setidaknya di bagian selatan Sulawesi. Eksploitasi yang tidak terkendali agaknya menjadi penyebab utama kelangkaan jenis kayu ini. Fenomena yang sama seperti yang ditemukan di kayu-kayu utama Sulawesi lannya semacam 'Eboni Sulawesi' (Diospyros celebica; Ebenaceae) dan 'Eboni Laut' (Diospyros maritima). 
Konservasi terhadap keragaman hayati Sulawesi, khususnya Sulawesi Selatan sangat penting untuk segera dilakukan. Dalam kaitan dengan ini, revitalisasi jalan trans Makassar Watampone, khususnya ruas Makassar - Maros harus diawasi dan dijaga dengan baik karena melintasi bagian terpenting dari Taman Nasional Bantimurung-Bulusaraung, yaitu Pegunungan Kapur/Karst Maros, di mana boleh jadi merupakan benteng terakhir keberadaan populasi 'Kayu Galadupa' (Sindora galedupa) di selatan Sulawesi, keberadaan 'dupa Bugis' di tanah air suku Bugis itu sendiri.

\section{Jejaring Bugis Nusantara (Bugis Nusantara Networking)}

Acara perhelatan Mattompang Arajang sendiri menjadi semacam reuni akbar masyarakat suku Bugis dari segala penjuru Indonesia dan Nusantara, di mana dalam acara tersebut juga dihadiri para perwakilan masyarakat Bugis dari dalam dan luar negeri Indonesia. Tercatat setidaknya beberapa utusan dari kerajaan-kerajaan di luar Indonesia yang memiliki latar belakang atau kaitan dengan Kerajaan Bone hadir, seperti:

a. Kerajaan Singapura (merupakan kerajaan adat yang diakui oleh pemerintah Republik Singapura meski dalam status warisan nasional)

b. Beberapa kerajaan di Malaysia seperti Johor, Kedah, Malaka, Pahang

c. Kerajaan Brunei Darussalam

Banyak kerajaan lain di Indonesia yang secara langsung atau tidak langsung berkaitan dengan suku dan budaya Bugis juga datang dalam Mattompang Arajang tahun ini, antara lain Kerajaan Buton, Gowa, Soppeng, Pangkajene, Palopo, dan lain-lain. Dapat disimpulkan di sini bahwa Mattompang Arajang dapat berfungsi sebagai ajang pemersatu segenap suku Bugis di Nusantara. Suatu ajang yang dapat dimanfaatkan sebagai dasar dari pembentuk sebuah jejaring (networking), khususnya terkait perniagaan yang sebenarnya sudah ada semenjak berabad-abad, bahkan mungkin sebelum kedatangan para saudagar dari Timur Tengah.

Kemampuan suku Bugis (dan juga suku-suku lain sekerabat seperti Buton, Makassar serta Mandar) dalam perniagaan bahari sudah dikenal lama, bahkan para saudagar Bugis tercatat dalam kitab Negara Kertagama di jaman Majapahit sebagai pelaut-pelaut dan saudagar-saudagar bahari yang baik. Pun oleh saudagar-saudagar Arab sudah berniaga, khususnya rempah-rempah dan logam (besi) hingga ke Madagaskar dan Pantai Timur Afrika serta pulau-pulau di sekitarnya, seperti Kepulauan Komoro, jauh sebelum kedatangan mereka ke wilayah-wilayah tersebut (Battuta, 1980; Cortesão, 2005). Peranan penting para pedagang Bugis dalam perniagaan antar pulau di dalam dan di luar wilayah Nusantara juga diakui oleh bangsa Portugis dan Belanda yang bahkan kerap memanfaatkan para saudagar Bugis sebagai pedagang perantara antara mereka dan bangsa-bangsa pribumi Nusantara, bahkan hingga Srilangka, India, Madagaskar, dan pantai timur dan selatan Afrika (Boxer, 1965; Boxer, 1977; França, 1970; Cook, 2007; Jayasuria, 2008).

Peranan suku Bugis sebagai pemain utama dalam perniagaan hasil bumi Nusantara, khususnya rempah-rempah bahkan mencapai puncaknya di masa Arung Palakka, di mana pada tahun 1662 bahkan ia diangkat sebagai raja di Ulakan, Pariaman, Minangkabau sekaligus tanpa tanding menggenggam jalur perniagaan di pantai barat Sumatera, bahkan hingga ke Srilangka dan pantai timur India, khususnya Malabar (Andaya, 1981); sementara jalur timur dipegangnya berbagi bersama dengan VOC. Saat itu, hanya Kerajaan Bone (kerajaan suku Bugis) yang mendapatkan keleluasaan untuk menulis surat langsung ke Gubernur Jenderal Belanda (Andaya, 2014). Berbekal pada fakta-fakta sejarah terkait networking suku Bugis, dalam kesempatan Mattompang Arajang sempat mendiskusikan 
kemungkinan untuk membangkitkan kembali poros maritim yang pernah dimiliki suku Bugis di masa silam dengan konteks kekinian. Dengan kata lain, revitalisasi jejaring maritim Bugis atau Bugis Nusantara Networking dalam bentuk Bugis Nusantara Trade and Cultural Networking. Meski untuk sementara ini masih dalam bentuk wacana dan penguatan literasi, namun ide ini layak dipertimbangkan berdasarkan fakta bahwa jejaring tradisional yang dilandasi kesamaan dan keterkaitan budaya trans-border, dalam hal ini Bugis, diyakini memiliki kekuatan perniagaan kokoh dan bertahan lama karena lebih adaptif dan saling menguatkan antar bandar. Sebagaimana dapat disaksikan bahwa hingga hari ini, kapal-kapal kayu dari suku Bugis dan kerabatnya (Buton, Makassar, Mandar) masih memadati pelabuhan Sunda Kelapa di Jakarta yang membawa aneka macam komoditi penting antar pulau, mulai dari beras, kayu hingga bahan-bahan bangunan.

Jejaring Bugis Nusantara juga dapat menjadi salah satu landasan kuat untuk upaya penyelamatan perahu-perahu tradisional Nusantara, seperti pinisi, padewakang, dan sejenisnya yang menghidupi pelayaran tradisional Nusantara yang juga secara de facto masih menghidupi perekonomian mikro dan bahkan dalam cakupan tertentu juga makro negara Indonesia. Dalam kaitan dengan acara adat Mattompang Arajang sebagai ajang pemersatu seluruh keturunan Bugis di Nusantara yang membentuk Jejaring Bugis Nusantara, keberadaan kemenyan Bugis sangat penting karena pada hakikinya tidak ada prosesi tersebut tanpa kehadiran kemenyan Bugis sehingga keberadaannya perlu dipertahankan. Ini berita bagus terkait dengan konservasi Sindora galedupa di bumi asalnya sendiri.

\section{KESIMPULAN}

Hasil penelitian ini menunjukkan bahwa wilayah yang saat ini termasuk ke dalam Kabupaten Bone adalah asal mula kebudayaan Bugis dan masih kuat menjaga kelestarian tradisi budaya Bugis, antara lain dalam bentuk prosesi (perhelatan) tahunan Mattompang Arajang yang dikaitkan dengan Hari Jadi Bone. Beberapa hal perlu mendapat perhatian seperti kelestarian komponen penting prosesi itu sendiri yaitu dupa atau kemenyan Bugis yang berasal dari sejenis tumbuhan polong-polongan (Fabaceae) yang dikenal sebagai 'Kayu Galadupa' yang diidentifikasi di sini sebagai Sindora galedupa. Sindora galedupa sendiri sudah jarang terlihat di hutan dan kemenyan Bugis itupun sudah sangat lama tidak digunakan. Perhelatan tahunan Mattompang Arajang Kabupaten Bone yang dihadiri segenap masyarakat berbudaya Bugis yang tersebar luas di Nusantara juga memiliki potensi untuk kebangkitan kembali budaya maritim Bugis yang pernah berhasil membawa kemakmuran dalam bentuk jejaring masyarakat Bugis di Nusantara atau Bugis Nusantara Networking. Jejaring ini juga dapat dijadikan landasan untuk mendukung prioritas nasional saat ini yaitu Poros Maritim berbasis komoditas asli Indonesia, khususnya rempah-rempah di mana kemenyan pun masuk ke dalamnya.

\section{UCAPAN TERIMA KASIH}

Penulis mengucapkan terimakasih yang sebesar-besarnya kepada Pemerintah Daerah Kabupaten Bone yang telah mengundang kami ke Watampone sehingga penelitian ini dapat dilakukan. Penghargaan juga dilayangkan ke Kementerian Koordinator bidang Kemaritiman yang telah memfasilitasi penulis untuk hadir dan melakukan riset di Bone. 


\section{DAFTAR PUSTAKA}

Andaya, L.Y. 1981. The heritage of Arung Palakka: A history of South Sulawesi (Celebes) in the seventeenth century. Martinus Nijhoff, The Hague.

Andaya, L.Y. 2014. Surat Raja Bone, La Patau Paduka Sri Sultan Indris Azim ud-din (berkuasa 1696-1714) \& Sira Daeng Talele Karaeng Ballajawa kepada Pemerintah Agung, 1697. In Carey P., Niemeijer, H.E., Nurjaman, J. (eds.). 2014. Harta karun: Khazanah sejarah Indonesia dan Asia-Eropa dari arsip VOC di Jakarta. Dokumen 17. Arsip Nasional Republik Indonesia, Jakarta, 1-16 p.

Audley-Charles, M.G. 1981. Geological history of the region of Wallace's Line. In: Whitmore, T.C. (eds.). 1981. Wallace's Line and plate tectonics. Clarendon Press, Oxford, 5-25 p.

Battuta, A.M. 1980. Travels in Asia and Africa 1325-1345. Routledge and Kegan Paul, London.

Bernard, H.R. 2006. Methods in anthropology $4^{\text {th }}$ edition. Alta Mira, Littlefield.

Boer, E., Ella, A.B., Tesoro, F.O. 2000. Plant producing exudates. Plant Resources in SouthEast Asia 18, Backhuys Publishers, Leiden.

Boxer, C.R. 1965. The Dutch seaborne empire 1600-1800. Penguin Books, London.

Boxer, C.R. 1977. The Portuguese seaborne empire 1415-1852. Penguin Books, London.

Cook, H.J. 2007. Matters of exchange: Commerce, medicine, and science in the Dutch Golden Age. Yale University Press, New Haven.

Cortesão, A. 2005. The 'Suma Oriental' of Tomé Pires: An account of the East, from the Red Sea to China, written in Malacca and India in 1512-1515, Vol. 1, $2^{\text {nd }}$ ed. Asian Educational Service, New Delhi.

Craig, R.D. 2004. Handbook of Polynesian mythology. ABC CLIO, Santa Barbara.

Cunningham, A.B. 2001. Applied ethnobotany: People, wild plant use and conservation. WWF and Earthscan Publications, London.

Druce, S.C. 2009. The lands west of the lakes: A history of the Ajattappareng Kingdoms of South Sulawesi, 1200 to 1600 CE. KITLV Press, Leiden.

Druce, S.C. 2016. Orality, writing \& history: The literature of the Bugis \& Makassar of South Sulawesi. International Journal of Asia Pacific Studies 12(1): 1-5.

França, A.D. 1970. Portuguese influence in Indonesia. Calouste Gulbenkian Foundation, Lisbon.

Groves, C., Shekelle, M. 2010. The genera and species of Tarsiidae. International Journal of Primatology 31(6): 1071-1082.

Hall, R. 1998. The plate tectonics of Cenozoic South East Asia and the distribution of land \& sea. In Hall, R., Holloway, J.D. (eds.). 1998. Biogeography and geological evolution of South East Asia. Backhuys Publication, Leiden, 99-131 p.

Hoent, C., Ziegler, K. 1917. Verslag ovede resultaten van geologisch - Mijnbouwkundige verkenningen in Z.W.Celebes.Jaarb. Mijnw. Verb 2: 235-363.

Holloway, J.D., Hall, R. 1998. South East Asian geology and biogeography: An introduction.

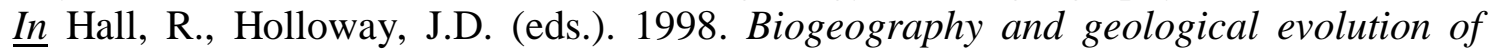
South East Asia. Backhuys Publication, Leiden, 1-23 p.

Jayasuriya, S.S. 2008. The Portuguese in the east: A cultural history of a maritime trading empire. Tauris Academic Studies, London.

Keßler, P.J.A., Bos, M.M., Sierra Daza, S.E.C., Kop, A., Willemse, L.P.M., Pitopang, R., Gradstein, S.R. 2002. Checklist of woody plants of Sulawesi, Indonesia. Blumea Supplement 14 (1): 1-160. 
Koorders, S.H. 1898. Flora van N.O. Celebes. Mededeelingen van 's Lands Plantentuin No. XIX, Gravenhage, Batavia (Jakarta).

Koorders-Schumacher, A. 1914. Systematisches verzeichnis: Der zum herbar Koorders gehörenden, in Niederländisch-Ostindien, besonders in den jahren 1888-1903 gesammelten. Phanerogamen und Pteridophyten IV Abteilung Celebes. Selbstverlag der Verfasserin, Buitenzorg (Bogor).

Krismawati, N.U., Warto., Suryati, N. 2018. Eksistensi Warok dan Gemblak di tengah masyarakat Muslim Ponorogo tahun 1960-1980. Religió 8(1): 116-138.

Lam, H.J. 1945a. Contributions to our knowledge of the flora of Celebes (collections of C. Monod de Froidville) and of some other Malaysian islands. Blumea 5(3): 554-599.

Lam, H.J. 1945b. Notes on the historical phytogeography of Celebes. Blumea 5(3): 600-640.

Langenheim, J.H. 2003. Plant resins: Chemistry, evolution, ecology and ethnobotany. Timber Press, Portland.

Lemmens, R.H.M.J., Soerianegara, I., Wong, W.C. (eds.) 1995. Timber trees: Major commercial timbers. Plant Resources in South-East Asia 5(2), Backhuys Publishers, Leiden.

Martin, G. 1995. Ethnobotany: A method manual. Chapman and Hill, New York.

Merrill, E.D. 1917. An interpretation of Rumphius's Herbarium Amboinense. Bureau of Sciences - Bureau of Printing, Manila.

Merrill, E.D. 1952. Notes on Xanthostemon F. Mueller and Kjellbergiodendron Burret. Journal of the Arnold Arboretum 33: 150-165.

Metcalfe, I. 1996. Pre-Cretaceous evolution of South East Asia terranes. $\underline{I n}$ Hall, R., Blundell, D. (eds.). 1996. Tectonic evolution of South East Asia. Geological Society Publication 106: $97-122$.

Murray, D.A.B. 2003. Who is Takatāpui?: Māori language, sexuality and identity in Aotearoa/New Zealand. Anthropologica 45 (2): 233-241.

Nolan, J.M., Turner, N.J. 2011. Ethnobotany: The study of people-plants relationships. $\underline{I n}$ Anderson, N.J., Pearsall, D., Hunn, E., Turner, N.J. (eds.). 2011. Ethnobiology. WilleyBlackwell, Hoboken, New Jersey, 133-148 p.

Pelras, C. 1979. L'oral et l'ecrit dans la tradition Bugis, Asie du Sud-est et Monde. Insulindien 10(2-4): 271-297.

Pelras, C. 1996. The Bugis. Blackwell, Oxford.

Petri, R.P. 1671. De Bugis Laur. Arnaud and Petri Borde, Amsterdam.

Ramos, M.D. 1990. Philippine myths, legends and folktales. CreateSpace, Manila.

Rheede tot Drakenstein, H. 1678. Horti Malabarici: Arboribus et fruticibus siliquosis: Vol. 1. Joannis van Somereen \& Joannis van Dyck \& Theodoris Boom, Amsterdam.

Rumphius, G.E. 1705. D'Amboinsche Rariteitkamer. François Halma, Amsterdam.

Rumphius, G.E. 1741a. Herbarium Amboinense, Vol. 1. François Changuion, Amsterdam.

Rumphius, G.E. 1771b. Herbarium Amboinense, Vol. 2. François Changuion, Amsterdam.

Rumphius, G.E. 1910. De Ambonsche historie, behelsende een kort verhaal der gedenkwaardigste geschiedenissen zo in vreede als oorlog voorgevallen sedert dat de Nederlandsche Oost Indische Comp. het besit in Amboina gehadt heeft. Bijdragen tot de Taal-, Land-en Volkenkunde, 64.

Rumphius, G.E. 2002. De Ambonse eilanden onder de VOC: Zoals opgetekend in De Ambonse landbeschrijving. Landelijk Steunpunt Educatie Molukkers, Utrecht.

Said, N. 2004. Religion and cultural identity among the Bugis. Inter-Religio 45: 12-20.

Sarasin, P.B., Sarasin, K.F. 1905. Reisen durch Celebes: 2 Vols. C.W. Kreidel's Verlag, Wiesbaden. 
Sharyn, G. 2001. Sulawesi's fifth gender: Inside Indonesia No. 66. Indonesian Resources and Information Program, Leiden.

Sharyn, G. 2002. Sex, gender and priests in South Sulawesi, Indonesia. The Newsletter No. 29, International Institute for Asian Studies, Leiden.

Sila, M.A. 2015. Mandu': A way of union with God. Australian National University, Canberra.

Supriatna, J., Wahyono, E.H. 2000. Panduan lapangan primate Indonesia. Yayasan Obor Indonesia, Jakarta.

Swain, T., Trompf, G. 1995. The religion of Oceania. Routledge, London.

Van Bemmelen, R.W. 1949. The geology of Indonesia. Government Printing Office and Nijhoff, The Hague.

Van Leeuwen, T.M. 1981. The geology of Southwest Sulawesi with special reference to the Biru area: The Geology and Tectonics of Eastern Indonesia. Geological Researches Development Centre, Special Publication 2: 277-304.

Whitmore, T.C. 1972. Leguminosae. In Whitmore, T.C. (eds.). 1972. Tree flora of Malaya: A manual for foresters, Vol. 1. Longman Malaysia, Kuala Lumpur, 270-273 p.

Whitten, A.J., Mustafa, M., Henderson, G.S. 1987. The ecology of Sulawesi. Gadjah Mada University Press, Yogyakarta.

Wiranata, A.D.W., Nurcahyo, A. 2018. Peranan Gemblak dalam kehidupan social tokoh Warok Ponorogo. Jurnal Agastya 8(1): 94-106. 